\title{
The Case for Grazing Dairy Cows
}

\author{
J. Michael Wilkinson ${ }^{1} \mathbb{D}$, A. Thomas Chamberlain ${ }^{2, *}$ and M. Jordana Rivero ${ }^{3} \mathbb{D}$ \\ 1 School of Biosciences, University of Nottingham, Loughborough, Leicester LE12 5RD, UK; \\ j.mike.wilkinson@gmail.com \\ 2 Chalcombe Ltd., Wickham, Hampshire PO17 5PQ, UK \\ 3 Rothamsted Research, North Wyke, Okehampton, Devon EX20 2SB, UK. \\ jordana.rivero-viera@rothamsted.ac.uk \\ * Correspondence: tom@chalcombe.co.uk
}

\section{check for}

updates

Citation: Wilkinson, J.M.; Chamberlain, A.T.; Rivero, M.J. The Case for Grazing Dairy Cows. Agronomy 2021, 11, 2466. https:// doi.org/10.3390/agronomy11122466

Academic Editor: Martin Gierus

Received: 20 October 2021

Accepted: 1 December 2021

Published: 3 December 2021

Publisher's Note: MDPI stays neutral with regard to jurisdictional claims in published maps and institutional affiliations.

Copyright: (c) 2021 by the authors. Licensee MDPI, Basel, Switzerland. This article is an open access article distributed under the terms and conditions of the Creative Commons Attribution (CC BY) license (https:// creativecommons.org/licenses/by/ $4.0 /)$.

\begin{abstract}
The case for grazing dairy cows at pasture is reviewed in six categories: (i) optimal land use for food production; (ii) soil carbon sequestration; (iii) carbon footprint; (iv) animal health and welfare; (v) effects on human health of milk produced from grazed pasture; and (vi) consumer demand for milk from grazed cows. Land best-suited to grazing is uncultivatable peaty soil receiving relatively low levels of fertilisation. With soil carbon sequestration, carbon footprint is lower for grazing than for other systems of milk production. Some indices of animal health and welfare (e.g., lameness, status of hock integument) are influenced positively by extent of grazing. Benefits to human health may accrue from higher levels of essential amino acids, carotenoids, omega- 3 fatty acids and conjugated linoleic acid in milk from cows given pasture compared to diets based on silage and concentrates. Milk producers, processors and supermarkets are responding to consumer demand for milk and milk products from cows given access to pasture during the grazing season. The major constraint to milk production from grazing is energy intake. Research opportunities to address this constraint include application of remote sensing and artificial intelligence to grazing management.
\end{abstract}

Keywords: milk production; soil health; carbon sequestration; animal welfare; human health

\section{Introduction}

There has been a trend in recent decades away from grazing, towards housed systems of milk production [1]. For example, in the 20-year period between 1990 and 2010, annual production of silage in the UK increased by 1 million tonnes of dry matter (DM) and production of compounds and blends increased by 0.6 million tonnes of DM [2]. In the same period, the total number of dairy cows decreased by $36 \%$ from 2.9 million to 1.8 million cows, whilst average annual milk yield per cow increased by $42 \%$ [3].

Further evidence of the decline in importance of grazing can be seen in national statistics for milk and concentrate feed production since 1990 (Figure 1) [2]. The rate of increase in compound and blend production per cow over the period 1990 to 2018 was greater than the rate of increase in milk production per cow, indicating decreased inputs of forage per cow $[4,5]$.

Against this trend, some dairy farmers have followed developments in Ireland and New Zealand, opting for a low-cost, low-output system of milk production based on spring calving and reliance on grazed pasture as the predominant feed for most of the year [4,5]. The emphasis is on output per hectare instead of output per cow $[4,5]$.

The economic implications of the decline in reliance on pasture were discussed in detail by Hurley and Murphy [6] in relation to Ireland and by Beca [7] for Australia and other milk exporting countries. They concluded that changes in production system away from high levels of pasture utilisation increased cost of feed per litre of milk, which was a major factor accounting for reduced profitability and, in the case of Australia, decreased total national annual milk output. 


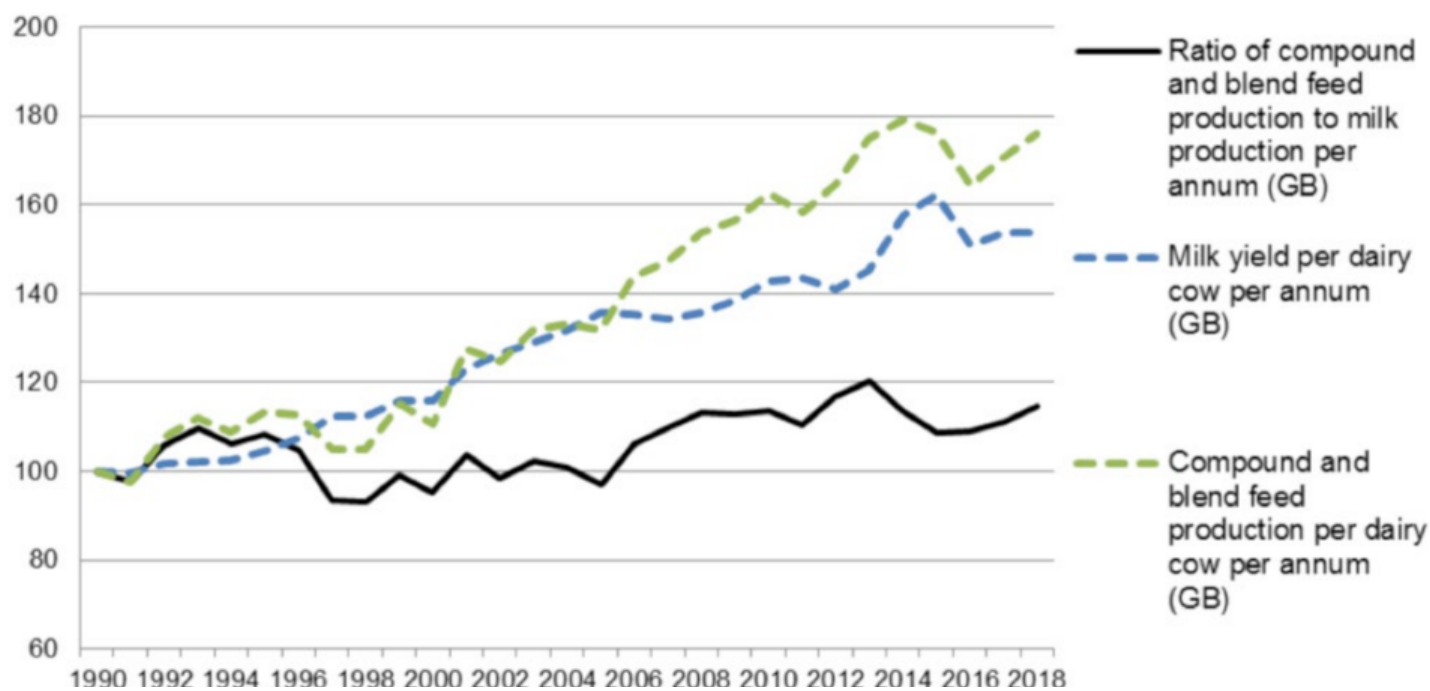

Figure 1. Trends in annual milk production and concentrate feed production per cow in Great Britain. $1990=100$ [2].

In this review, the case for grazing dairy cows is considered under six headings: (i) optimal land use for food production; (ii) soil carbon sequestration; (iii) carbon footprint; (iv) animal health and welfare; (v) effects on human health of milk produced from grazed pasture; and (vi) consumer demand for milk from grazed cows. Major constraints to milk production from grazed dairy cows are reviewed together with some research and development opportunities created by recent technological advances.

\section{Optimal Land Use for Food Production}

The capability of land to produce human food depends on soil type, topography and climate [8]. Some peaty soils in upland, wetlands and high-rainfall regions are not suited to producing human food by soil cultivation and arable cropping, i.e., production of crops such as cereal grains, oilseeds and pulses, but are suitable for grazing [8]. To determine whether a net gain in food output might accrue from the use of a particular type of land by grazing pasture rather than through arable cropping, the land use ratio (LUR) concept developed by Van Zanten et al. [8] may be used. The LUR is defined as the maximum amount of human digestible protein (HDP) produced from food crops grown on the area of land used to produce one kilogram of animal product divided by the amount of HDP in one kilogram of animal product. A LUR value $>1.0$ indicates that the land would be better used for the production of arable crops whereas a value $<1.0$ implies that the optimal use of that land would be for the production of ruminant milk or meat. For example, van Zanten et al. [8] calculated that the LUR for dairy cows was 2.10 when the animals were kept on sandy soils and 0.67 when kept on peaty soils. The LUR was lower for cows on peaty soils than for sandy soils because the peaty soils were unsuitable for direct production of food crops [8].

The UK has 6.2 million hectares of permanent grassland (i.e., more than 5 years old), excluding rough grazing (mountains, hills, heathland and moorland), accounting for $36 \%$ of the total utilised agricultural area [9]. Most permanent grassland is not suitable for cultivation due to soil type and topography, and therefore is grazed by cattle and sheep. This land represents a valuable resource for human food production.

An alternative approach involves evaluating the efficacy of contrasting livestock systems in terms of total land required per unit of animal output. Comparison of a range of livestock systems revealed that forage-based milk production required a similar total area of land per tonne of animal protein to that of poultry meat production, normally regarded as the most efficient livestock system (Table 1). Moreover, forage-based milk production required around $17 \%$ less land per tonne of animal protein than eggs or pig meat. Thus, increasing productivity per hectare of grazed land can enhance efficiency of forage-based milk production even further compared with other livestock systems. 
Table 1. Land required per tonne of animal protein output for a range of livestock systems [10].

\begin{tabular}{cccc}
\hline Livestock System & \multicolumn{3}{c}{ Land Required (ha/t Animal Protein) } \\
\hline & Arable & Grassland & Total \\
\hline Milk (forage-based) & 0.62 & 2.50 & 3.12 \\
Poultry meat & 3.13 & - & 3.13 \\
Cereal beef & 3.05 & 0.19 & 3.24 \\
Eggs & 3.74 & - & 3.74 \\
Pig meat & 3.80 & - & 3.80 \\
Dairy beef & 1.62 & 7.26 & 8.88 \\
Lowland suckler beef & 2.04 & 14.2 & 16.2 \\
Upland suckler beef & 0.94 & 17.5 & 18.4 \\
Lowland lamb & 1.10 & 21.4 & 22.5 \\
Upland lamb & 1.58 & 26.0 & 27.6 \\
\hline
\end{tabular}

\section{Soil Carbon Sequestration}

Many agricultural soils have been degraded due to prolonged periods of arable cropping and a range of management strategies is available to achieve soil carbon sequestration (reviewed by Paustian et al. [11]). One such strategy is conversion of arable land to grassland which can increase levels of soil organic carbon (SOC), at least in the first decade following conversion. In a 30-year experiment on the same soil type, spring barley arable cropping was compared with a ryegrass/white clover sward [12]. Both crops received low levels of mineral fertiliser annually and the pasture was grazed each year. Trends in soil carbon and nitrogen are shown in Figure 2.

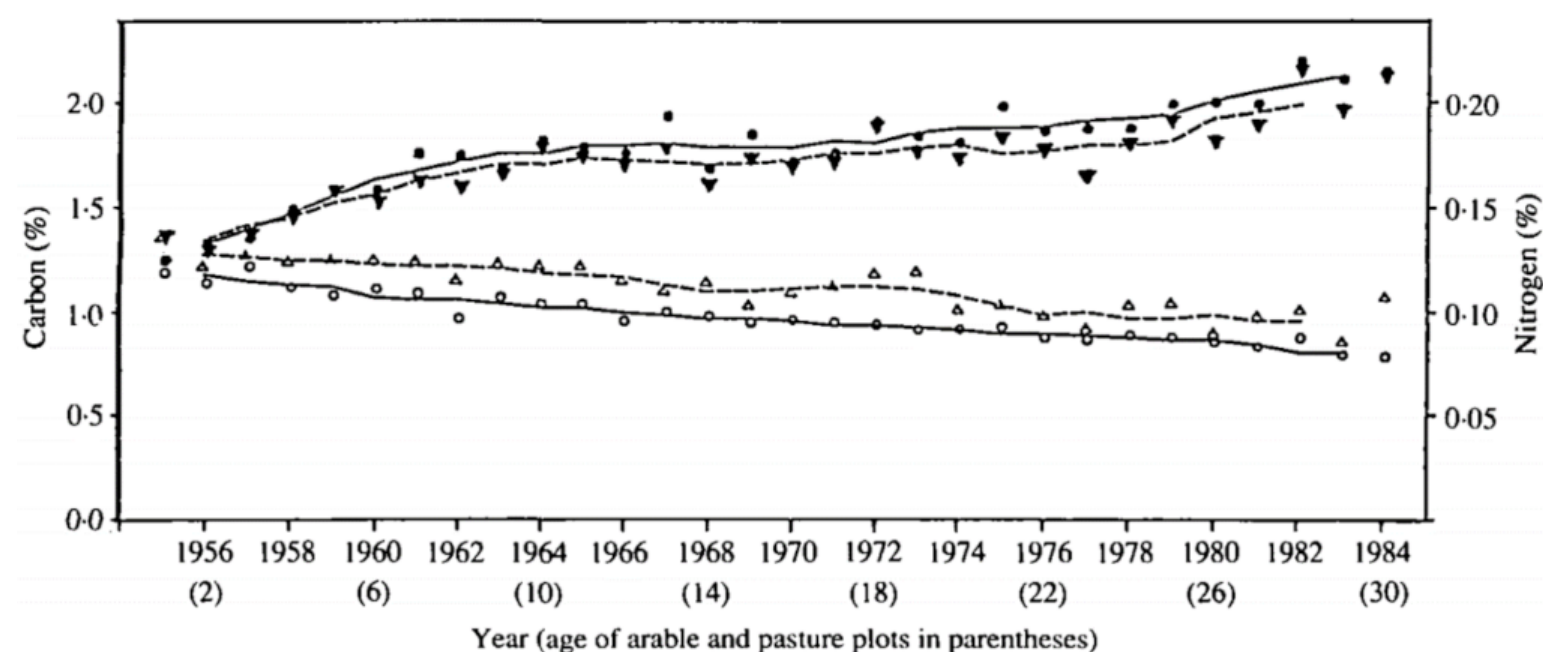

Figure 2. Soil organic carbon (circles) and N (triangles) under arable cropping (open symbols) or grazed pasture (solid symbols) to $15 \mathrm{~cm}$ depth, 1955 to 1984 [12].

Under arable cultivation, the annual loss in weight of SOC to $15 \mathrm{~cm}$ depth between 1955 and 1984 was $250 \mathrm{~kg} / \mathrm{ha}$ per year and the loss in weight of $\mathrm{N}$ was $25 \mathrm{~kg} / \mathrm{ha}$ per year. Under pasture, SOC and N increased, especially during the first ten years after establishment, at rates of $1000 \mathrm{~kg} \mathrm{SOC} /$ ha per year and $75 \mathrm{~kg}$ N/ha per year. Grassland in rotation with arable cropping can ameliorate the loss of SOC from continuous arable cropping, especially on sandy soils with low levels of SOC [13]. Soil carbon sequestration occurs at a greater and more sustained rate in degraded land sown to multiple plant species including legumes, compared to a single grass species [14]. Thus, there are opportunities to remediate SOC levels in regions where soil fertility is low as the result of continuous arable production by integrating grazed multi-species pasture into crop rotations, with the added benefit of carbon and nutrient recycling via livestock manure. 
Comprehensive studies of greenhouse gas fluxes in European grasslands with livestock [15] indicated average (213 site years) mean net carbon storage of $760 \pm 110 \mathrm{~kg} \mathrm{C} / \mathrm{ha}$ per year, significantly greater than zero $(p<0.001)$. The critical stocking rate to achieve pasture carbon neutrality, with $70 \mathrm{~kg} \mathrm{~N} /$ ha applied as manure, and accounting for enteric methane and soil nitrous oxide emissions, is 1.2 livestock units per hectare over a 200-day grazing season. However, a relatively low efficiency of herbage utilisation of 0.3 to 0.4 (ratio of herbage intake to net above-ground primary productivity) is required to achieve the critical stocking rate [15]. Following this approach to milk production from grazed pasture, larger areas of pasture may be needed to produce the same amount of milk.

In a five-year French comparison of grazing with mowing [16], gross primary productivity (negative values indicate carbon uptake from the atmosphere via photosynthesis) was similar between the two management systems. However, ecosystem respiration was $21 \%$ higher and net ecosystem exchange (NEE) of $\mathrm{CO}_{2}$ between the ecosystem and the atmosphere (the difference between productivity and respiration) was $52 \%$ lower for grazing than mowing. Net carbon storage, although highly variable, tended to be higher for grazing than for mowing, indicating that temperate sown grasslands have the potential to sequester carbon when grazed but not when mown (Table 2).

Table 2. Annual carbon flux in grassland: grazing vs. mowing [16].

\begin{tabular}{|c|c|c|c|c|c|}
\hline & Mowing & SE & Grazing & SE & $p$ Value \\
\hline & \multicolumn{5}{|c|}{$\mathrm{g} \mathrm{C} / \mathrm{m}^{2}$ per Year } \\
\hline Gross primary productivity & -1720 & 88.5 & -1741 & 79.8 & 0.7951 \\
\hline Ecosystem respiration & 1244 & 70.5 & 1510 & 90.0 & 0.0401 \\
\hline Net ecosystem exchange (NEE) & -476 & 51.8 & -231 & 73.5 & 0.0222 \\
\hline Net carbon storage (NCS) ${ }^{1}$ & 22.7 & 32.3 & 140.9 & 69.9 & 0.1543 \\
\hline
\end{tabular}

${ }^{1}$ NCS = NEE minus C in hay (cutting) and methane + milk (grazing).

Comparison of rotational with continuous grazing over a single 221-day season revealed no differences in average cumulative NEE between the two systems at similar overall stocking rates; $-66 \mathrm{~g} \mathrm{C} / \mathrm{m}^{2}$ for rotational vs. $-74 \mathrm{~g} \mathrm{C} / \mathrm{m}^{2}$ for continuous grazing, despite short-term differences between the two systems in $\mathrm{CO}_{2}$ flux dynamics [17]. In particular, $\mathrm{CO}_{2}$ from respiration by the grazing animal can play a significant role in affecting NEE [18]. For example, an increase in respiration rate due to heat stress could decrease NEE.

\section{Carbon Footprint of Milk Production}

In addition to net carbon flux, environmental impact of different milk production systems is also assessed in terms of enteric methane emissions, nitrogen use efficiency (NUE, milk $\mathrm{N}$ as a percentage of total $\mathrm{N}$ intake) and diet carbon footprint [19]. It is generally accepted that across a range of diets, methane emissions per unit of milk output decrease and NUE increases with increasing level of daily milk output per cow, mainly due to dilution of the maintenance component.

The effect of diet and level of daily milk output on methane production, diet carbon footprint and NUE is shown in Table 3. Diets were formulated to meet energy and protein requirements of cows giving 20 or 30 litres of milk daily and given either grazed pasture grass with limited concentrate supplementation or grass silage and concentrates. The diet based on grazed grass had a lower carbon footprint than that based on silage, however, NUE was higher for the silage-based diet. Diet carbon footprint and methane were lower, and NUE was higher at $30 \mathrm{~kg}$ milk/day than at $20 \mathrm{~kg}$ milk/day, highlighting the need to increase milk production from grazed pasture to reduce environmental impact per kilogram of milk produced per cow daily. 
Table 3. Effect of type of diet and daily milk output on methane production, diet carbon footprint and NUE [19].

\begin{tabular}{|c|c|c|c|c|c|c|}
\hline & Diet & & $\begin{array}{l}\text { Average Milk } \\
\text { Yield (kg/day) }\end{array}$ & $\begin{array}{c}\text { Methane (kg } \\
\mathrm{CO}_{2} \mathrm{e} / \mathrm{kg} \text { Milk) }\end{array}$ & $\begin{array}{c}\text { Diet Carbon Footprint } \\
(\mathrm{kg} \mathrm{CO} 2 \mathrm{e} / \mathrm{kg} \text { Milk) }\end{array}$ & $\operatorname{NUE}^{1}(\%)$ \\
\hline \multirow[t]{2}{*}{ Grazed pasture } & Grass silage & Concentrate & & & & \\
\hline & $\%$ of total DM) & & & & & \\
\hline 70 & - & 30 & 20 & 0.465 & 0.317 & 21 \\
\hline- & 70 & 30 & 20 & 0.495 & 0.430 & 29 \\
\hline 70 & - & 30 & 30 & 0.345 & 0.278 & 28 \\
\hline- & 48 & 52 & 30 & 0.320 & 0.315 & 34 \\
\hline
\end{tabular}

${ }^{1}$ Nitrogen Use Efficiency.

Assessment of total carbon footprint using national UK data for different milk production systems [20] revealed higher carbon footprint for dairy herds given access to grazing for 270 days per year than for those given grazing for 180 or zero days per year (Table 4). However, no account was taken in this analysis of carbon sequestration in soils under grazed pasture.

Table 4. Carbon footprint of contrasting systems of milk production [20].

\begin{tabular}{cccc}
\hline & \multicolumn{2}{c}{ Grazing Access (Days per Year) } \\
\hline & 270 & 180 & 0 \\
\hline Energy-corrected milk yield (kg/cow/year) & 5500 & 7800 & 9200 \\
Land use (ha per cow + replacements/year) & 0.6 & 0.5 & 0.5 \\
of which: & & & \\
Grazing & 0.4 & 0.1 & 0.0 \\
Silage & 0.1 & 0.3 & 0.3 \\
Imported feed & 0.1 & 0.1 & 0.2 \\
Carbon footprint (kg CO2e/kg milk) & 1.3 & 1.1 & 1.0 \\
\hline
\end{tabular}

In a national survey of 415 commercial dairy farms in Great Britain [21], average carbon footprint was $1.17 \mathrm{~kg} \mathrm{CO}_{2} \mathrm{e} /$ litre of fat-corrected milk. Enteric emissions accounted for $38 \%$ of total carbon footprint and feed production for $24 \%$ of total emissions. These findings were confirmed in a study of 1964 UK dairy farms supplying the cooperative milk processor Arla [22]. In the Arla study, average carbon footprint was $1.13 \mathrm{~kg} \mathrm{CO} 2 \mathrm{e} /$ litre of milk, of which enteric emissions accounted for $46 \%$ and feed production $37 \%$ of total emissions. In the DairyCo study [21], there was a trend of higher carbon emissions with increasing level of concentrate feed use per litre of milk produced (Figure 3).

$\mathrm{O}^{\prime}$ Brien et al. [23], in a detailed life-cycle analysis of three contrasting systems of milk production, used an average value from the available literature of $1190 \mathrm{~kg} \mathrm{CO}$ per hectare per year to estimate carbon sequestration by grassland soil. They calculated, for a high-efficiency grass-based system comprising $77 \%$ of total annual DM intake as grazed pasture DM supporting a milk output of $6695 \mathrm{~kg}$ energy corrected milk per year, total carbon footprint was $0.914 \mathrm{~kg} \mathrm{CO} \mathrm{CO}_{2} \mathrm{e} / \mathrm{kg}$ milk without soil carbon sequestration, which was similar to the footprint of confinement systems. However, this value was reduced to $0.837 \mathrm{~kg} \mathrm{CO} \mathrm{CO}_{2} \mathrm{e} / \mathrm{kg}$ milk when soil carbon sequestration was included in the analysis, $5 \%$ lower than a housed system, indicating that efficient grazing can potentially reduce the carbon footprint of milk production compared to systems based on silage and concentrates. 


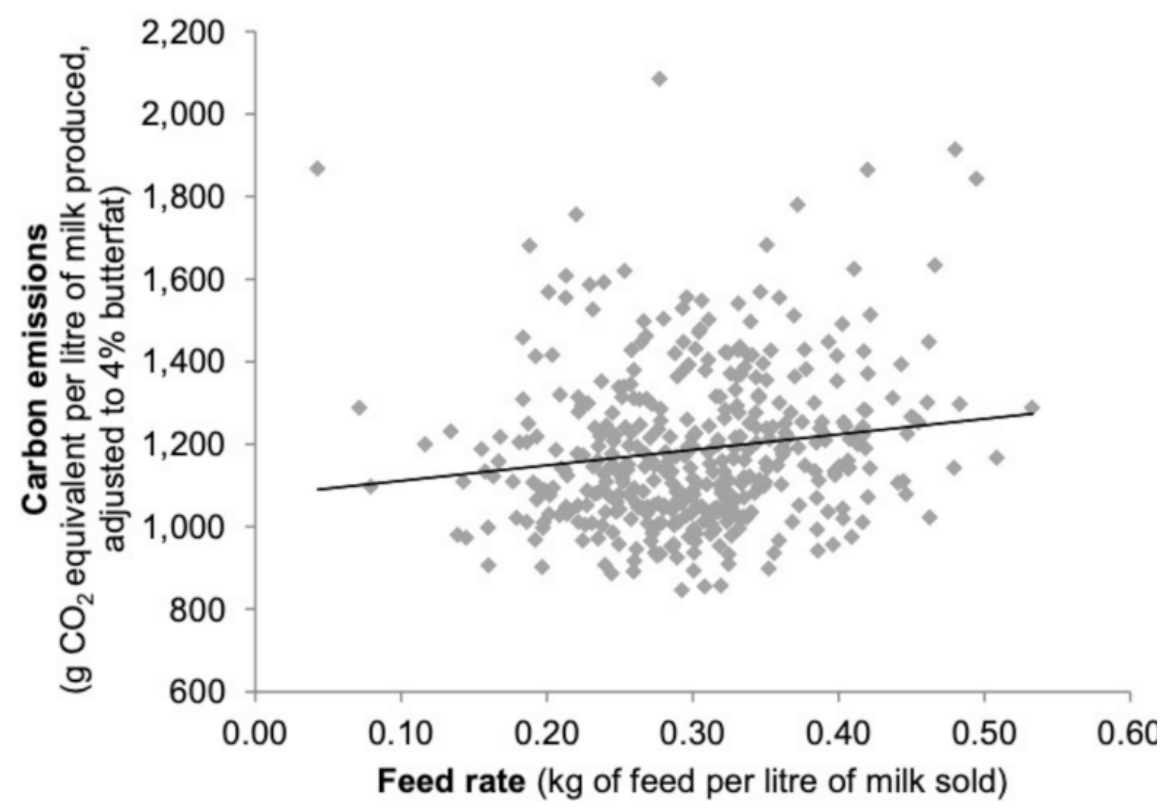

Figure 3. Carbon footprint and concentrate feed use per litre of milk produced on 415 commercial farms in Great Britain [21].

\section{Animal Health and Welfare}

Diseases of dairy cows and replacement heifers reduce milk yield and quality, increasing cost of production and carbon footprint per unit of milk. There is evidence that extent of grazing and level of purchased feed input may be linked to animal health status. Ertl et al. [24] studied milk output, and fertility and veterinary input to pasturebased organic dairy herds in Austria given different levels of concentrate supplementation. The main findings of the study, which involved 148 farms over a two-year period, are summarised in Table 5. Farms were divided into four groups according to level of total annual concentrate input (zero (C0), less than 975 (C1), 976 to 1400 (C2) and above $1400 \mathrm{~kg}$ fresh weight/cow per annum (C3)). Average herd size was similar between groups at 26 cows/herd.

Table 5. Effect of level of concentrate input on milk production and herd health in pasture-based dairy herds [24].

\begin{tabular}{|c|c|c|c|c|c|}
\hline & \multicolumn{4}{|c|}{ Level of Concentrate ${ }^{1}$} & \multirow[t]{2}{*}{$p$-Value } \\
\hline & $\mathrm{CO}$ & $\mathrm{C} 1$ & $\mathrm{C} 2$ & $\mathrm{C} 3$ & \\
\hline Concentrates (kg/cow/year) & $7 d$ & $710 \mathrm{c}$ & $1237 \mathrm{~b}$ & $1657 a$ & $<0.001$ \\
\hline Energy-corrected milk (kg/cow/year) & $5093 b$ & $5813 a$ & $6597 a$ & $6824 a$ & $<0.001$ \\
\hline Calving interval (days) & $410 \mathrm{a}$ & $396 a b$ & $393 a b$ & $388 b$ & 0.03 \\
\hline Veterinary costs ( $€$ /cow / year $)$ & $26.2 \mathrm{c}$ & $59.3 b c$ & $73.8 \mathrm{a}$ & $71.1 \mathrm{ab}$ & 0.001 \\
\hline Veterinary costs ( $€$ cent $/ \mathrm{kg}$ milk) & 0.51 & 1.05 & 1.13 & 1.06 & 0.051 \\
\hline Marginal income ( $€$ cent $/ \mathrm{kg}$ milk) & $31.2 \mathrm{a}$ & $27.5 b$ & $25.7 \mathrm{c}$ & $24.7 \mathrm{c}$ & $<0.001$ \\
\hline
\end{tabular}

${ }^{1}$ Means with different letters differ statistically.

Milk yield increased with greater concentrate input. Calving interval was longer for the herds given forage-only diets (C0). Insemination index and 90-day non-return rates were similar between groups of herds. Veterinary costs were markedly lower for $\mathrm{C} 0$ than for the other groups. Despite reduced milk output, marginal income per kg milk was highest for the forage-only diet, with no differences in profitability (revenue minus direct costs) between groups of farms. This study demonstrated that those dairy herds with total reliance on grazed and conserved grassland have improved health status, indicated by a lower incidence of animal health issues that required veterinary input. 
Pasture access also benefits dairy cow behaviour, in terms of grazing, improved lying/resting times, lower levels of aggression, more normal oestrous behaviours and better synchronicity of behaviours than confined cows [25-27]. Burow et al. [28] studied 17 criteria of welfare in 41 Danish dairy herds, all of which gave cows access to grazed pasture for at least $5 \mathrm{~h}$ per day for at least 120 days/year. The criteria of welfare were combined into a weighted 'welfare index' (WI). They found that WI was improved in summer compared to winter and for herds that employed day and night grazing compared to day-only grazing. The hock joint integument was the criterion most improved by grazing. Burow et al. [29] found the more time cows spent at pasture, the lower their mortality.

Perceived animal welfare benefits accruing from grazing have been incorporated in legislation in Sweden. The Swedish Animal Welfare Ordinance requires that cattle are grazed at pasture in the summer months [30].

\section{Effects on Human Health of Milk Produced from Grazed Pastures}

Nutritionally functional components in milk can offset adverse environmental impacts (reviewed by McAuliffe et al. [31]) and there is evidence that addition of milk to the diet, in general, can benefit long-term human health [32]. Thus, milk and milk products produced from pasture-based systems can be considered to be functional foods, exhibiting health benefits beyond their basic nutritional value. In addition to being a source of essential amino acids, lipids, vitamins and minerals, milk derived from grazed pastures exerts other beneficial health properties due to the presence of elevated levels of bio-active molecules including natural antioxidants such as alpha-tocopherol, iso-flavones, polyunsaturated fatty acids and conjugated linoleic acid [33,34].

In a three-year comparison of pasture with indoor feeding in lowland Switzerland, Hofstetter et al. [35] found that yields of milk, fat and protein were higher for cows kept indoors and given a diet comprising silage and concentrate than for cows given pasture. However, milk of cows on pasture contained higher levels of omega-3 fatty acids $(1.7 \mathrm{v} 0.9 \mathrm{~g} / 100 \mathrm{~g}$ fat) and conjugated linoleic acid ( $1.9 \mathrm{v} 0.6 \mathrm{~g} / 100 \mathrm{~g}$ fat) than milk from cows given silage and concentrates. Interestingly, milk fatty acids may be used as biomarkers to discriminate productions obtained in different seasons in order to enhance the economic value of seasonal productions with better health characteristics [36].

Milk from cows grazed on pasture as the sole feed is more suitable for processing compared to that from cows given mixed diets of grass and silage or concentrates. Cows offered $6 \mathrm{~kg}$ DM/day as silage or concentrates supplements to grazed pasture produced milk with lower levels of total protein and true protein. Further, concentrations of casein and casein peptides $(\alpha s 1, \alpha s 2, \beta, \kappa)$ were also reduced in milk from supplemented cows compared to cows given grazed grass alone [37]. There is also evidence that offering cows more than $3 \mathrm{~kg}$ fresh weight/day of palm kernel meal as a pasture supplement can adversely affect the quality of milk for processing [38], due to reduced levels of total protein, elevated levels of total fat and increased proportions of saturated fatty acids, especially lauric acid (C12:0).

\section{Consumer Demand for Milk from Grazed Cows}

Grass-based production systems have been used as a marketing approach by retailers and processors because consumers perceive pasture-based systems as more 'natural' and therefore better for cow welfare and the environment [39]. Supermarkets and milk buyers in Europe are setting targets and standards that require dairy cows to graze pasture. This initiative has resulted in an increase in the percentage of dairy farms incorporating grazing into their herd management strategy [40]. Nevertheless, such strategies rely on the consumer valuing these commitments by being willing to pay more for milk produced from grazed than from housed cows.

In the UK, the supermarket chain Marks and Spencer Ltd. requires that milking cows are provided with access to grazing for at least $4 \mathrm{~h}$ per day for at least 100 days and farmers are encouraged to provide pasture access whenever weather conditions permit as part of 
their 'Plan A 2025 Sustainability Plan' [41]. Similarly, Waitrose and Partners Ltd. require that cows graze for at least $4 \mathrm{~h}$ a day for a minimum of 120 days a year [42]. The producer cooperative First Milk Ltd. has asked its members to sign up to their First4 Milk Pledge which involves farmers agreeing to provide cows with access to pasture for a minimum of $6 \mathrm{~h}$ per day for 120 days during the grazing season [43].

In the Netherlands, Fromagerie Bel SA, producers of Leerdammer cheese, is committed, together with its 1200 local milk producers, to producing milk from cows grazing for at least $6 \mathrm{~h}$ daily for 120 days per year [44]. The UK producer group 'Free-Range Dairy Farmers', supplying the supermarket chain Associated Dairies Ltd. (ASDA), has gone further in contracting producers to 180 days and nights a year at pasture as part of their 'Pasture Promise' [45]. These products can be differentiated through special labels, and consumers can access accurate information about the production conditions, because traceability and transparency are highly appreciated by consumers [46].

\section{Constraints to Milk Production from Grazing}

Potential areas of concern for animal health and welfare in pasture-based systems may include physiological indicators of more severe negative energy balance, greater risk of internal parasitism, malnutrition (especially of micro-nutrients), delayed onset of oestrous activity postpartum and, in some situations, the potential for compromised welfare due to exposure to unpredictable and extreme weather conditions $[25,27,47]$, including heat stress [48].

Many North American Holstein-type cows are not well-suited to grazing. The suitability of cow genotype for grazing was discussed by Knaus [1], who concluded that lighter-weight cows are better able to maintain body condition, have improved fertility, cause less damage to pasture in wet weather and may have advantages over heavier cows in terms of longevity. Wilkinson and Lee [10], Wilkinson et al. [5] and Hennessey et al. [4] reviewed factors limiting milk output per cow at pasture, of which daily herbage intake was the most significant.

Theoretical relationships between energy demand and energy intake at different levels of metabolizable energy in forage are illustrated in Figure 4. At a typical pasture ME level of 11.6 MJ ME $/ \mathrm{kg} \mathrm{DM}$, predicted energy intake and energy demand are equal at a daily milk yield of 35 litres. In practice, milk yield is likely to be some 15 litres lower, at 20 litres per day. Knaus [1] calculated that $61 \%$ of the milk loss at pasture was due to reduced energy intake, $24 \%$ to increased activity and $12 \%$ to higher urea excretion compared to a total mixed ration.

In Danish production settings, available farmland close to cow barns is typically scarce and cows often have to walk long distances on stony and/or muddy tracks between milking and grazing, increasing the risk of lameness, in addition to increasing man hours and labour [49]. Thus, grazing was excluded in extreme weather conditions in the Danish Act on Keeping of Dairy Cattle and the Offspring of Dairy Cattle [50] and it was compensated by more space indoors [51].

Conversion of degraded arable land to grassland may offer opportunities to increase soil carbon sequestration, but this type of land does not have the infrastructure (e.g., buildings, milking equipment, fencing, water, access tracks to paddocks) to support grazed herds of dairy cows. Further, lack of rainfall in arable regions can limit the extent to which grazing contributes to total feed supply and duration of grazing season. 


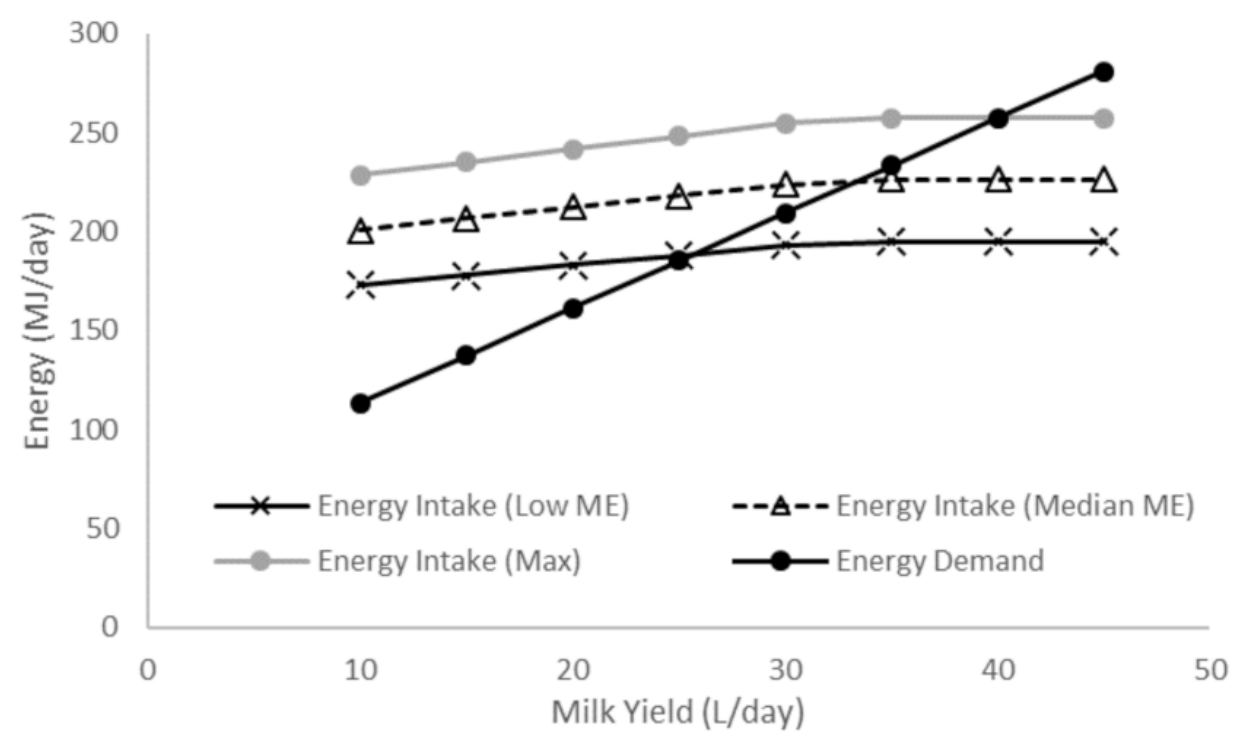

Figure 4. Theoretical relationship between energy demand for milk production and energy intake predicted from a low ME forage (10 MJ $/ \mathrm{kg} \mathrm{DM})$, median ME (11.6 MJ $/ \mathrm{kg} \mathrm{DM})$ and the theoretical maximum ME level in forage (13.6 MJ/kg DM). From Wilkinson and Lee [10].

\section{Research Opportunities}

There is a need to find ways of quantifying and sustaining soil carbon sequestration to offset emissions from enteric fermentation and feed production, which together comprise the majority of total emissions from dairy farms [20-22]. In a major study of carbon emissions from UK dairy farms, soil carbon sequestration is recognised as a major factor in moving toward net zero emissions in milk production, because $79 \%$ of the land occupied by dairy farms that supply Arla is used to grow grass [22], yet at present carbon sequestration is not included in carbon footprint accounting.

Remote sensing of temperate grasslands is developing as a potentially useful tool in pasture management $[4,5,52]$. Automated cloud-based techniques are also being developed to monitor cow behaviour and allocate pasture so that the cow receives additional herbage in synchrony with her eating behaviour. Linking remote-sensed grazing management with artificial intelligence offers promising opportunities to develop user-friendly tools to improve pasture management so that herbage production and intake is optimised in relation to sward type and weather conditions. Automated recording of total time spent grazing introduces the possibility of objectively validating producer compliance with contractual obligations with milk purchasers.

There is need to undertake research into the key components of grazing management systems to quantify critical control points such as grazing infrastructure on the farm (fields, fences, water supply, animal access), field location, herbage growth and annual yield, identification of individual animal and herd positions and behaviours, automation of herbage allocation per cow and rapid, accurate, analysis of animal responses to changes in pasture quality and quantity. Potential new technologies to improve grazing management and efficiency have been reviewed elsewhere [5] but little work is underway to address these research needs in the context of higher-yielding dairy cows with high fixed costs per cow and utilising hybrid grazing/housing systems used in many northern European farms.

A current UK research project (GrazeMore, Innovate UK [53]) is focused on developing innovative technologies to allow dairy cows to determine, according to their grazing behaviour, when additional pasture allocations should occur, rather than the decision as to when to allocate fresh pasture being made by the herd manager. Small, collar-mounted sensors are used to track grazing cows in commercial herds using Global Positioning Satellite (GPS) fixes and to monitor grazing behaviour in real time through accelerometer data. Herd grazing behaviour is used to determine when to allocate extra grazing. A signal is generated to trigger a field gate to open, allowing the herd access to fresh pasture. 
Preliminary results indicate that this novel technology can give significant increases in daily herbage intake without reducing grazing efficiency but more work is needed to verify the extent to which the approach can support higher milk yields from pasture as the sole feed in a range of different grazing situations.

\section{Conclusions}

The case for grazing can be made, but restricted herbage intake and low milk output per cow limit the adoption of grazing in higher-yielding commercial dairy herds. Despite evidence that grazing can increase soil carbon sequestration, much arable land does not have the infrastructure required to support livestock. However, there is cause for limited optimism. Improved methods of grazing management, involving new technologies supported by research and development involving progressive milk producers, should lead to a higher proportion of milk of superior quality being produced from grazed grasslands to satisfy growing consumer demand.

Author Contributions: Conceptualization, J.M.W. and A.T.C.; investigation, J.M.W. and A.T.C.; resources, J.M.W., A.T.C. and M.J.R.; writing—original draft preparation, J.M.W., A.T.C. and M.J.R.; project administration, J.M.W. and A.T.C.; funding acquisition, J.M.W., A.T.C. and M.J.R. All authors have read and agreed to the published version of the manuscript.

Funding: This work was funded by the UK's innovation agency, Innovate UK, Project 105150: The use of GPS tracking and the LoRaWAN network to improve productivity of grazing dairy cows. M. Jordana Rivero was partially funded by the UK Biotechnology and Biological Sciences Research Council (BBSRC) through the grant BBS/E/C/000I0320 (Soil to Nutrition ISP).

Conflicts of Interest: The authors declare no conflict of interest. The funders had no role in the design of the study; in the collection, analyses, or interpretation of data; in the writing of the manuscript, or in the decision to publish the results.

\section{References}

1. Knaus, W. Perspectives on pasture versus indoor feeding of dairy cows. J. Sci. Food Agric. 2016, 96, 9-17. [CrossRef]

2. DEFRA. Agricultural Statistics and Climate Change. Available online: https://assets.publishing.service.gov.uk/government/ uploads/system/uploads/attachment_data/file/835762/agriclimate-9edition-02oct19.pdf (accessed on 30 March 2020).

3. Wilkinson, J.M.; Wray, A.E. Changes in the production of silage and ruminant concentrate feeds in the United Kingdom between 1990 and 2010. In Proceedings of the XVI International Silage Conference, Hämeenlinna, Finland, 2-4 July 2012; Kuoppala, K., Rinne, M., Vanhatalo, A., Eds.; MTT Agrifood Research Finland: Hämeenlinna, Finland, 2012; pp. 190-191.

4. Hennessy, D.; Delaby, L.; van den Pol-van Dasselaar, A.; Shalloo, L. Increasing grazing in dairy cow milk production systems in Europe. Sustainability 2020, 12, 2443. [CrossRef]

5. Wilkinson, J.M.; Lee, M.R.F.; Rivero, M.J.; Chamberlain, A.T. Some challenges and opportunities for grazing dairy cows on temperate pastures. Grass Forage Sci. 2020, 75, 1-17. [CrossRef]

6. Hurley, C.; Murphy, M. Building a Resilient, Flourishing, Internationally Competitive Dairy Industry in Ireland. Report to the 2025 Agri Food Strategy Committee. Available online: https:/ / www.agriculture.gov.ie/media/migration/foodindustrydevelopmenttrademarkets / 2025agri-foodstategy/publicconsultationsubmissions/representativebodies/DairyIndustryReportConHurleysub260115.pdf (accessed on 2 April 2020).

7. Beca, D. Remedying the Loss of Profitability and Declining Milk Production in the Australian Dairy Industry. Available online: http:/ / www.redskyagri.com/file/pdf/Remedying_declining_milk_production_in_the_Australian_dairy_industry-Beca. pdf (accessed on 2 April 2020).

8. van Zanten, H.H.E.; Mollenhorst, H.; Klootwijk, C.W.; van Middelaar, C.E.; de Boer, I.J.M. Global food supply: Land use efficiency of livestock systems. Int. J. Life Cycle Assess. 2016, 21, 747-758. [CrossRef]

9. DEFRA. Agriculture in the United Kingdom. 2018. Available online: https://assets.publishing.service.gov.uk/government/ uploads/system/uploads/attachment_data/file/848641/AUK_2018_09jul19a.pdf (accessed on 31 March 2020).

10. Wilkinson, J.M.; Lee, M.R.F. Review: Use of human-edible animal feeds by ruminant livestock. Animal 2018, 12, 1735-1743. [CrossRef]

11. Paustian, K.; Larson, E.; Kent, J.; Marx, E.; Swan, A. Soil C sequestration as a biological negative emission strategy. Front. Clim. 2019, 1, 8. [CrossRef]

12. Tyson, K.C.; Roberts, D.H.; Clement, C.R.; Garwood, E.A. Comparison of crop yields and soil conditions during 30 years under annual tillage or grazed pasture. J. Agric. Sci. 1990, 115, 29-40. [CrossRef] 
13. Johnston, A.E.; Poulton, P.R.; Coleman, K. Chapter 1 Soil organic matter: Its importance in sustainable agriculture and Carbon dioxide fluxes. In Advances in Agronomy; Sparks, D.L., Ed.; Academic Press: Burlington, ON, Canada, 2009; Volume 101, pp. 1-57, ISBN 978-0-12-374817-1.

14. Yang, Y.; Tilman, D.; Furey, G.; Lehman, C. Soil carbon sequestration accelerated by restoration of grassland biodiversity. Nat. Commun. 2019, 10, 718. [CrossRef]

15. Soussana, J.F.; Klumpp, K.; Ehrhardt, F. The role of grassland in mitigating climate change. In EGF at 50: The Future of European grasslands, Proceedings of the 25th General Meeting of the European Grassland Federation; Wales, UK, 7-11 September 2014, Hopkins, A., Collins, R.P., Fraser, M.D., King, V.R., Lloyd, D.C., Moorby, J.M., Robson, P.R.H., Eds.; IBERS, Aberystwyth University: Aberystwyth, Wales, 2014; pp. 75-87.

16. Senapati, N.; Chabbi, A.; Gastal, F.; Smith, P.; Mascher, N.; Loubet, B.; Cellier, P.; Naisse, C. Net carbon storage measured in a mowed and grazed temperate sown grassland shows potential for carbon sequestration under grazed system. Carbon Manag. 2014, 5, 131-144. [CrossRef]

17. Gourlez de la Motte, L.; Mamadou, O.; Beckers, Y.; Bodson, B.; Heinesch, B.; Aubinet, M. Rotational and continuous grazing does not affect the total net ecosystem exchange of a pasture grazed by cattle but modifies $\mathrm{CO}_{2}$ exchange dynamics. Agric. Ecosyst. Environ. 2018, 253, 157-165. [CrossRef]

18. Puche, N.; Senapati, N.; Flechard, C.R.; Klumpp, K.; Kirschbaum, M.U.F.; Chabbi, A. Modeling carbon and water fluxes of managed grasslands: Comparing flux variability and net carbon budgets between grazed and mowed systems. Agronomy 2019, 9, 183. [CrossRef]

19. Wilkinson, J.M.; Garnsworthy, P.C. Dietary options to reduce the environmental impact of milk production. J. Agric. Sci. 2017, 155, 334-347. [CrossRef]

20. CIEL. Net Zero Carbon \& UK Livestock. Available online: https:/ /www.cielivestock.co.uk/net-zero-carbon-and-uk-livestock/ (accessed on 28 October 2020).

21. DairyCo. Greenhouse Gas Emissions on British Dairy Farms-Dairy Co Carbon Footprinting Study: Year Three (2012-2013); Kenilworth. 2014. Available online: https://projectblue.blob.core.windows.net/media/Default/ResearchPapers/Dairy/411045_carbon_ footprint_report_year_3_final.pdf (accessed on 31 March 2020).

22. Arla. Report: A Sustainable Future for British Dairy. Available online: https://news.arlafoods.co.uk/news/arla-launches-newreport-revealing-carbon-footprint-data-from-almost-2-000-dairy-farms-and-the-steps-being-taken-to-reduce-farm-emissionsby-30-percent-by-2030 (accessed on 5 October 2021).

23. O'Brien, D.; Capper, J.L.; Garnsworthy, P.C.; Grainger, C.; Shalloo, L. A case study of the carbon footprint of milk from high-performing confinement and grass-based dairy farms. J. Dairy Sci. 2014, 97, 1835-1851. [CrossRef]

24. Ertl, P.; Knaus, W.; Steinwidder, A. Comparison of zero concentrate supplementation with different quantities of concentrates in terms of production, animal health, and profitability of organic dairy farms in Austria. Org. Agric. 2014, 4, 233-242. [CrossRef]

25. Arnott, G.; Ferris, C.P.; O'connell, N.E. Review: Welfare of dairy cows in continuously housed and pasture-based production systems. Animal 2017, 11, 261-273. [CrossRef] [PubMed]

26. Wagner, K.; Brinkmann, J.; March, S.; Hinterstoißer, P.; Warnecke, S.; Schüler, M.; Paulsen, H.M. Impact of daily grazing time on dairy cow welfare-results of the welfare quality ${ }^{\circledR}$ protocol. Animals 2018, 8, 1. [CrossRef] [PubMed]

27. Mee, J.F.; Boyle, L.A. Assessing whether dairy cow welfare is "better" in pasture-based than in confinement-based management systems. N. Z. Vet. J. 2020, 68, 168-177. [CrossRef] [PubMed]

28. Burow, E.; Rousing, T.; Thomsen, P.T.; Otten, N.D.; Sorensen, J.T. Effect of grazing on the cow welfare of dairy herds evaluated by a multidimensional welfare index. Animal 2013, 7, 834-842. [CrossRef] [PubMed]

29. Burow, E.; Thomsen, P.T.; Sørensen, J.T.; Rousing, T. The effect of grazing on cow mortality in Danish dairy herds. Prev. Vet. Med. 2011, 100, 237-241. [CrossRef]

30. Swedish Ministry of Enterprise and Innovation. The Animal Welfare Ordinance (2019:66), Chapter 2, Section 3. Available online: https:/ / www.government.se/494c6c/contentassets/934374dfdabf43e5993dc67a974ec24e/animal-welfare-ordinancesfs-2019-66-12-mars-2020.pdf (accessed on 1 April 2020).

31. McAuliffe, G.A.; Takahashi, T.; Lee, M.R.F. Applications of nutritional functional units in commodity-level life cycle assessment (LCA) of agri-food systems. Int. J. Life Cycle Assess. 2020, 25, 208-221. [CrossRef]

32. Stylianou, K.S.; Heller, M.C.; Fulgoni, V.L.; Ernstoff, A.S.; Keoleian, G.A.; Jolliet, O. A life cycle assessment framework combining nutritional and environmental health impacts of diet: A case study on milk. Int. J. Life Cycle Assess. 2016, 21, 734-746. [CrossRef]

33. Ferlay, A.; Martin, B.; Pradel, P.; Coulon, J.B.; Chilliard, Y. Influence of grass-based diets on milk fatty zcid composition and milk lipolytic system in Tarentaise and Montbéliarde cow breeds. J. Dairy Sci. 2006, 89, 4026-4041. [CrossRef]

34. Descalzo, A.M.; Rossetti, L.; Páez, R.; Grigioni, G.; García, P.T.; Costabel, L.; Negri, L.; Antonacci, L.; Salado, E.; Bretschneider, G.; et al. Differential characteristics of milk produced in grazing systems and their impact on dairy products. In Milk Production-Advanced Genetic Traits, Cellular Mechanism, Animal Management and Health; Chaiyabutr, N., Ed.; InTech: Rijeka, Croatia, 2012; pp. 339-368.

35. Hofstetter, P.; Frey, H.-J.; Gazzarin, C.; Wyss, U.; Kunz, P. Dairy farming: Indoor v. pasture-based feeding. J. Agric. Sci. 2014, 152, 994-1011. [CrossRef]

36. Maniaci, G.; Di Grigoli, A.; Bonanno, A.; Giosuè, C.; Ilardi, V.; Alabiso, M. Fatty acids as biomarkers of the production season of caciocavallo palermitano cheese. Animals 2021, 11, 2675. [CrossRef] 
37. Reid, M.; O’Donovan, M.; Murphy, J.P.; Fleming, C.; Kennedy, E.; Lewis, E. The effect of high and low levels of supplementation on milk production, nitrogen utilization efficiency, and milk protein fractions in late-lactation dairy cows. J. Dairy Sci. 2015, 98, 5529-5544. [CrossRef]

38. New Zealand Farmers Weekly. Limit Palm Kernel Feed: Fonterra. Available online: https://farmersweekly.co.nz/\# (accessed on 18 November 2018).

39. Shortall, O. Cows eat grass, don't they? Contrasting sociotechnical imaginaries of the role of grazing in the UK and Irish dairy sectors. J. Rural Stud. 2019, 72, 45-57. [CrossRef]

40. van den Pol, A.; Becker, T.; Fernandez, A.B.; Hennessy, T.; Peratoner, G. Social and economic impacts of grass based ruminant production. In Sustainable Meat and Milk Production from Grasslands, Proceedings of the 27th General Meeting of the European Grassland Federation, Cork, Ireland, 17-21 June 2018; Horan, B., Hennessy, D., O’Donovan, M., Kennedy, E., McCarthy, B., Finn, J.A., O’Brien, B., Eds.; European Grassland Federation EGF: Cork, Ireland, 2018; pp. 697-708.

41. Marks and Spencer Ltd. Plan A Dairy Raw Materials, Commodities and Ingredients. Select Farm Assurance-Milk Production. Available online: https://corporate.marksandspencer.com/sustainability/food-and-household/product-standards/rawmaterials-commodities-and-ingredients / dairy\#0f5fcc3b1ea2463b82cf1efe99151f5d (accessed on 3 April 2020).

42. Waitrose and Partners Ltd. Animal Welfare Policies. Available online: https://www.waitrose.com/home/inspiration/about waitrose/the_waitrose_way/waitrose_animal_welfarecommitments.html (accessed on 3 April 2020).

43. First Milk. First Milk Launches First4Milk Pledge-A New Commitment to Sustainable Dairy. Available online: http://www. firstmilk.co.uk/news/2020 / first-milk-launches-first4milk-pledge-a-new-commitment-to-sustainable-dairy/ (accessed on 3 April 2020).

44. Leerdammer. Leerdammer's Free Grazing Promise. Available online: https:/ /www.leerdammer.co.uk/free-grazing-promise/ (accessed on 3 April 2020).

45. Free Range Dairy Farmers Pasture Promise. Available online: https://www.freerangedairyfarmers.co.uk/more-info (accessed on 3 April 2020).

46. Arraño, C.; Báez, A.; Flor, E.; Whay, H.R.; Tadich, N. Estudio preliminar del uso de un protocolo para evaluar el bienestar de vacas lecheras usando observaciones basadas en el animal. Arch. Med. Vet. 2007, 39, 239-245. [CrossRef]

47. Fisher, A.D.; Webster, J.R. Dairy cow welfare: The role of research and development in addressing increasing scrutiny. Anim. Prod. Sci. 2013, 53, 924-930. [CrossRef]

48. Galán, E.; Llonch, P.; Villagrá, A.; Levit, H.; Pinto, S.; Del Prado, A. A systematic review of non-productivityrelated animal-based indicators of heat stress resilience in dairy cattle. PLoS ONE 2018, 13, e0206520. [CrossRef]

49. Otten, N.D.; Rousing, T.; Houe, H.; Thomsen, P.T.; Sørensen, J.T. Comparison of animal welfare indices in dairy herds based on different sources of data. Anim. Welf. 2016, 25, 207-215. [CrossRef]

50. Danish Ministry of the Environment and Food. Promulgation of the Law on the Keeping of Dairy Cattle and Offspring of Dairy Cattle. LBK NO. 5811 January 2017. Available online: https://www-retsinformation-dk.translate.goog/eli/lta/2017/58?_x_tr_ $\mathrm{sl}=\mathrm{da \&} \_\mathrm{x} \_t r \_t \mathrm{t}=\mathrm{en} \& \_\mathrm{x} \_t \mathrm{tr}$ hll=en\&_x_tr_pto=nui,sc (accessed on 2 October 2021).

51. Otten, N.D.; Rousing, T.; de Oliveira, V.H.S.; Reiten, M.; Michelsen, A.M.; Hakansson, F.; Lund, V.P.; Houe, H.; Denwood, M.; Sørensen, J.T; et al. A weak point analysis of welfare in Danish dairy herds using two different welfare assessment systems. Anim. Welf. 2020, 29, 197-207. [CrossRef]

52. Wachendorf, M.; Fricke, T.; Möckel, T. Remote sensing as a tool to assess botanical composition, structure, quantity and quality of temperate grasslands. Grass Forage Sci. 2018, 73, 1-14. [CrossRef]

53. InnovateUK. Results of Competition: Productive and Sustainable Crop and Ruminant Agricultural Systems. Available online: https://assets.publishing.service.gov.uk/government/uploads/system/uploads/attachment_data/file/813610 /Competition_Results_-_Productive__Sustainable_Crop__Ruminant_Agricultural_Systems.pdf (accessed on 3 January 2021). 